\title{
Vaccinations in Hajj
}

\author{
Maha A Al Molaiki* and Meshael M Al Rasheed \\ Pharmaceutical Care Services, King Abdulaziz Medical City, Riyadh
}

Submission: November 21, 2017; Published: February 09, 2018

*Corresponding author: Maha A Al Molaiki, Pharmacy Practice Resident (PGY1) Pharmaceutical Care Services, King Abdulaziz Medical City, Riyadh, Tel: +966-11-8011111; Email: almolaikima@ngha.med.sa

\section{Introduction and Background}

More than 2 million people are expected to make the Hajj pilgrimage to Mecca, Saudi Arabia every year. It is one of the world's largest mass gatherings with people from more than 180 different countries around the world. In such a huge human gathering, pilgrims are at high risk to be exposed to different infectious agents. The most common reported infections mainly include respiratory, gastrointestinal and liver diseases. Influenza, common cold, bronchitis, sinusitis and pneumonia are the most prevalent respiratory diseases while gastroenteritis, food poisoning and hepatitis are the commonest gastrointestinal and liver infections. Vaccination requirements are one of the major preventive strategies that have been implemented to prevent such infections. Every year, the Saudi Arabian Ministry of Health $(\mathrm{MOH})$ sets a specific vaccination requirement as a fundamental part for pilgrims to obtain their Hajj visas. For this upcoming Hajj season (2017/1438H), required vaccinations include:

a. Yellow fever vaccine for visitors from certain African and South American countries.

b. Meningococcal meningitis (polysaccharide or conjugate vaccines) mandatory for visitors from all countries.

c. Poliomyelitis [oral polio vaccine (OPV) or inactivated poliovirus vaccine (IPV)] for visitors from certain countries.

d. Seasonal Influenza vaccine for those at high risk of severe influenza diseases (including pregnant women, children greater than 5 years old, elderly, and individuals with pre-existing health conditions).

\section{Reminders}

i. $\mathrm{MOH}$ strongly recommend updating immunization against vaccine-preventable diseases in all travellers. ii. Administration of meningococcal vaccine no less than 10 days before Hajj

iii. Seasonal influenza vaccination is recommended for all health-care workers in Hajj related areas

iv. Most vaccines are among Look-Alike, Sound-Alike (LASA) medication group, improper and unsafe vaccines handling can result in serious errors

v. Most vaccines must be stored in a refrigerator or freezer, and many require protection from light

\section{Safety Tips}

I. For frequently administered vaccines, establish standard order sets or protocols.

II. Post a quick reference for clinicians to verify the route of administration for all vaccines.

III. Highlight the route of administration on vaccine carton labels by circling or using color to bring attention to the information as necessary.

IV. Store vaccines with similar packaging or names on different refrigerator or freezer shelves to lessen the risk of errors.

V. Establish an ongoing education to staff who may prescribe dispense and administer vaccines (physicians, pharmacists and nurses).

KSA Ministry of Health currently advises against travel to the Hajj for pregnant women or children; if they choose to travel, these groups should receive meningococcal vaccination according to licensed indications for their age. (Table-1) 
Table 1: Health Requirements for Travellers to Saudi Arabia for Pilgrimage to Makkah (2017/1438H Hajj).

\begin{tabular}{|c|c|c|c|c|}
\hline Vaccine & Indication & Dose & When to Take it & Population \\
\hline Yellow fever & Yellow fever & One dose & $\begin{array}{l}\text { Certificate becomes valid } \\
10 \text { days after vaccination } \\
\text { and is good for } 10 \text { years. }\end{array}$ & $\begin{array}{c}\text { Africa: } \\
\text { Angola, Benin, Burkina Faso, Burundi, Cameroon, Central } \\
\text { African Republic, Chad, Congo, Côte d'Ivoire, Democratic } \\
\text { Republic of the Congo, Equatorial Guinea, Ethiopia, Gabon, } \\
\text { Gambia, Ghana, Guinea, Guinea Bissau, Kenya, Liberia, Mali, } \\
\text { Mauritania, Niger, Nigeria, Senegal, Sierra Leone, Sudan, } \\
\text { The Republic of South Sudan, Togo and Uganda. } \\
\text { Americas: } \\
\text { Argentina, Bolivarian Republic of } \\
\text { Venezuela, Brazil, Colombia, Ecuador, French Guyana, } \\
\text { Guyana, Panama, Paraguay, Peru, Plurinational State of } \\
\text { Bolivia, Suriname and Trinidad and Tobago. }\end{array}$ \\
\hline Meningococcal & Meningitis & $\begin{array}{l}\text { a. Conjugate } \\
\text { vaccine(Menveo/ } \\
\text { Nimenrix)-single } \\
\text { dose } \\
\text { b. Polysacch } \\
\text { aride vaccine } \\
\text { (ACWYVax) } \\
\text { single dose }\end{array}$ & $\begin{array}{l}\text { a. Not more than } 5 \text { years } \\
\text { and not less than } 10 \text { days } \\
\text { prior to arrival in Saudi } \\
\text { Arabia } \\
\text { b. Not more than } 3 \text { years } \\
\text { and no less than } 10 \text { days } \\
\text { prior to arrival in Saudi } \\
\text { Arabia } \\
\text { c. Valid for } 5 \text { years }\end{array}$ & $\begin{array}{l}\text { All arrivals from countries within the African Meningitis } \\
\text { Belt (Benin; Burkina Faso; Cameroon; Chad; Central } \\
\text { African Republic; Cote d'Ivoire; Eritrea; Ethiopia; Gambia; } \\
\text { Guinea; Guinea-Bissau; Mali; Niger; Nigeria; Senegal, Sudan } \\
\text { and South Sudan) will also be administered antibiotic } \\
\text { treatment at the point of entry as an added precaution. } \\
\\
\text { In the UK, visas will not be issued unless proof of } \\
\text { vaccination, atleast } 10 \text { days prior to the expected date of } \\
\text { entry, is submitted with the visa application. }\end{array}$ \\
\hline Poliomyelitis & Polio virus & $\begin{array}{l}\text { One dose of oral } \\
\text { polio vaccine } \\
\text { (OPV) }\end{array}$ & $\begin{array}{l}\text { a. Within the previous } 12 \\
\text { months and at least } 4 \\
\text { weeks prior to departure. } \\
\text { b. All travelers from the } \\
\text { mentioned countries in } \\
\text { the right column will also } \\
\text { receive } 1 \text { dose of OPV at } \\
\text { border points on arrival in } \\
\text { Saudi Arabia. }\end{array}$ & $\begin{array}{c}\text { a. States infected with Wild Polio } \\
\text { Virus } 1 \text { or circulating Vaccine Derived Polio Virus with } \\
\text { potential risk of international spread: Afghanistan, Nigeria } \\
\text { and Pakistan. } \\
\text { b. States no longer infected but remain vulnerable to } \\
\text { reinfection: Cameroon, Central African Republic, Chad, } \\
\text { Guinea, Laos People's Democratic Republic, Madagascar, } \\
\text { Myanmar, Niger and Ukraine. } \\
\text { c. States which remain vulnerable to Polio: Democratic } \\
\text { Republic of the } \\
\text { Congo, Equatorial Guinea, Ethiopia, Iraq, Kenya, Liberia, } \\
\text { Sierra Leone, Somalia, South Sudan, Syrian Arab Republic } \\
\text { and Yemen. }\end{array}$ \\
\hline $\begin{array}{l}\text { Influenza } \\
\text { vaccine }\end{array}$ & $\begin{array}{l}\text { Seasonal } \\
\text { influenza }\end{array}$ & One dose & Prior to arrival & $\begin{array}{l}\text { a. International pilgrims be vaccinated against seasonal } \\
\text { influenza with most recently available vaccines (i.e. } \\
\text { those for Southern Hemisphere 2016) particularly those } \\
\text { at increased risk of severe influenza diseases including } \\
\text { pregnant women, children aged over } 5 \text { years, the elderly } \\
\text { and individuals with pre-existing health conditions such } \\
\text { as asthma, chronic heart or lung diseases and HIV/AIDS } \\
\text { infection. } \\
\text { b. In Saudi Arabia, seasonal influenza vaccination is } \\
\text { recommended for internal pilgrims, particularly those with } \\
\text { pre-existing health conditions as described above, as well } \\
\text { as for all healthcare workers in the Hajj premises. }\end{array}$ \\
\hline $\begin{array}{l}\text { Zika virus } \\
\text { disease and } \\
\text { Dengue }\end{array}$ & $\begin{array}{l}\text { The Aedes aegypti } \\
\text { mosquito has not } \\
\text { been detected } \\
\text { in the Hajj and } \\
\text { Umrah areas } \\
\text { for many years; } \\
\text { however this } \\
\text { mosquito is } \\
\text { present in } \\
\text { surrounding } \\
\text { cities. }\end{array}$ & $\begin{array}{c}\text { Take insect } \\
\text { bite avoidance } \\
\text { measures }\end{array}$ & $\begin{array}{l}\text { During daytime and night } \\
\text { time hours to reduce the } \\
\text { risk of infection. }\end{array}$ & $\begin{array}{l}\text { For travellers arriving from areas with Zika virus } \\
\text { transmission, it is recommended to follow WHO advice. }\end{array}$ \\
\hline
\end{tabular}

All travelers from the mentioned countries in the right column will also receive 1 dose of OPV at border points on arrival in Saudi Arabia. 
The pregnant should postpone hajj in the following cases

A. Preterm birth disease history

B. Early miscarriage cases

C. Suffering from pregnancy diabetes

D. Heart and hypertension diseases or kidney patients and others

\section{Infants and children during the hajj}

It is recommended not to be accompanied by children who are not at puberty during the Hajj for the following reason:

a. Children are more vulnerable to infection with diseases such as respiratory tract and digestive tract infections or gastroenteritis.

b. Children are more vulnerable to lose fluids than adults either because of the high temperature or the little water they consume. c. Exhaustion tires children during the Hajj and could suppress their appetite; hence leading to the loss of body fluid.

d. Children are more vulnerable to get lost because of the overcrowding during the Hajj [1-4].

\section{References}

1. Salim P, Joanna G (2017) Saudi Arabia: Hajj/Umrah Pilgrimage. Centers for Disease Control and Prevention, Atlanta GA, USA.

2. Seyed Razavi, Mina Saeednejad, Payman Salamati (2016) Vaccination in Hajj: An Overview of the Recent Findings. Int J Prev Med 7: 129.

3. Ministry of Health (2017) Health Requirements for Travelers to Saudi Arabia for Pilgrimage to Makkah (2017/1438H Hajj).

4. ISMP (2015) Recommendations for Practitioners To Prevent Vaccine Errors Part 2: Analysis Of ISMP Vaccine Errors Reporting Program (VERP).

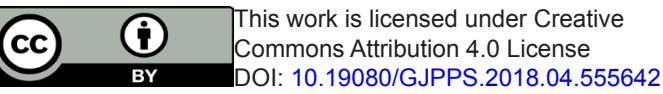

- Quality Editorial service

- Swift Peer Review

- Reprints availability

- E-prints Service

- Manuscript Podcast for convenient understanding

- Global attainment for your research

- Manuscript accessibility in different formats

( Pdf, E-pub, Full Text, Audio)

- Unceasing customer service

Track the below URL for one-step submission https://juniperpublishers.com/online-submission.php 